\title{
"DEFENDING AN ENGLISHMAN'S CASTLE" CAN I SELL MY HOUSE BUT CONTINUE LIVING IN IT? THE NORTH-EAST PROPERTY BUYERS LITIGATION
}

\author{
Robert Pearce
}

\section{INTRODUCTION}

The maxim "an Englishman's home is his castle" has its roots in Magna Carta. English land law has developed from a feudal system which emphasised the authority of the lord: in times long ago most occupiers of land were beholden in some way to their lord for their rights to the land, being obliged to give services in return for their landholding, and to demonstrate loyalty or fealty to their lord. The lords themselves had similar obligations to their lords, and ultimately to the King. Hence, it used to be said that all land in England was held directly or indirectly from the Crown.

Magna Carta did not undermine the feudal foundations of landholding - that has happened progressively over the years to the point where it now no longer has any real significance. However, it did make it clear that the rights of the King were not absolute. King John had been compelled by his barons to reach the agreement with them which was recorded in the first Magna Carta (or, to give it its English title, the Great Charter) signed and sealed at Runnymede in 1215 . Not only did the King need to heed his barons, Magna Carta importantly established the subsequently developed principle that no person is above the law and that "No free man shall be ... stripped of his rights or possessions ... except by the lawful judgement of his equals or by the law of the land." It is in congruity with this that it was held in Semayne's case at the start of the seventeenth century that not even agents of the Crown may enter a person's house without lawful authority. ${ }^{1}$ We can trace the maxim that an Englishman's home is his

\footnotetext{
Robert Pearce, BCL, MA, Hon LLD, FRSA, Professor of Law, University of Buckingham Law School.

${ }^{1}$ See Semayne's Case (1604) 5 Coke Rep 91.
} 
castle back to this case. ${ }^{2}$ Even if an Englishman's home did not have a motte and bailey, or other fortified defences, it would be protected by the force of the law.

This does not mean that landowners have unfettered and unqualified rights to their home. A homeowner is no more above the law than the King (or the barons) and must comply with the laws of the land. Landowners cannot hide from the process of law for criminal acts committed within the boundaries of their property; homeowners have legal duties for the safety of visitors (even uninvited visitors); they are restricted in how they use or develop the property by planning laws; most importantly in this context they may find that their security in their own home is compromised if they have used it to secure a loan which they are unable to repay. Although the proportion of houses bought for cash has increased to over a third in recent years, ${ }^{3}$ the majority of house purchases continue to be financed with the aid of a mortgage. Originally mortgages worked by a landowner transferring away legal ownership as security for the loan, but with a right to recover full ownership on repayment of the loan. The surrender of legal ownership made it clear that the castle defences had been breached and that the owner was vulnerable if the loan was not repaid. The anachronistic means of using a transfer of title as the means of granting security for a loan has now been clumsily abolished, ${ }^{4}$ but the risk of losing the home if the loan is not repaid remains. As secured loan advertisements remind us:

"Your home may be repossessed if you do not keep up repayments on your mortgage."

\section{EQUITY RELEASE SCHEMES}

It is not just when a house is purchased that a mortgage may be taken out. Rising house prices have meant that some people are asset rich but income poor. It is tempting for a person in this position to seek to access

\footnotetext{
${ }^{2}$ For a more recent invocation of the maxim, see Malik $v$ Fassenfelt [2013] EWCA Civ 798.

${ }^{3}$ See Hamptons International News Release 27 March 2014: 'Buoyant first time and cash buying puts pressure on supply.'

${ }^{4}$ See Stevens and Pearce, Land Law (London, $5^{\text {th }}$ ed, Sweet and Maxwell 2013) paras 17.13-17.15 and 17.25-17.28.

${ }^{5}$ This is the warning currently given by mortgage lenders and on comparison websites such as Money Super Market:

http://www.moneysupermarket.com/mortgages/.
} 
their capital to improve their standard of living. Alternatively, the equity in a house arising from progressively increasing house prices may be seen as a source of refinancing debt, or even repaying debt. The North East Property Buyers (NEPB) litigation concerns one way in which this could be done: through a sale and lease back. This kind of arrangement has been common for years in the commercial sector. The owner of property sells it to a finance or property management company. This releases some or most of the capital value in the property. The purchasing company then rents the property back to the seller. In this way the seller retains the use of the property, albeit in return for continuing rental payments. Of course, if the rent is not paid, then the seller will lose the use of the property.

\section{SALE AND LEASE BACK WITH MORTGAGE}

However, as the NEPB litigation demonstrates, a failure by the seller to pay rent is not the only risk. If the company purchasing the property has taken out a mortgage to finance the acquisition, then the seller may be at risk if the buyer fails to make the mortgage repayments. This is exactly what happened in the NEPB litigation.

\section{THE NEPB LITIGATION}

NEPB operated a scheme under which it bought houses, often from people who had run into debt through illness or unemployment, and offered them the chance to continue living there, often at a substantially discounted rent. It financed the purchases through mortgage loans secured on the properties purchasee. NEPB defaulted on the mortgages and the lenders, who were unaware of the arrangements with the sellers, sought possession of the properties from the sellers in order to sell them and redeem the mortgage. Press reports suggested that there could be around 2,000 people in danger of eviction. ${ }^{6}$ According to Detective Chief Inspector Jim McAll, of Northumbria Police: "If proven, and if it is on the scale alleged, it will probably be one of the biggest property frauds in the country."

\footnotetext{
${ }^{6}$ The Journal (Newcastle upon Tyne) 19 September 2013.

http://www.thejournal.co.uk/news/north-east-news/police-cuts-could-damagenorth-6062049.

7 Northern Echo 'Arrests in Darlington, Newton Aycliffe and Barnard Castle' Tuesday 2 March 2010.
} 
Were the mortgage companies entitled to evict sellers who had been promised a home for life? Nine ${ }^{8}$ cases were selected as test cases, and were heard at first instance by Judge Behrens, sitting as a judge of the High Court in Leeds. ${ }^{9}$ He decided in favour of the lenders. Some of the cases were settled, but others were appealed to the Court of Appeal, which again decided in favour of the lenders. ${ }^{10}$ One, involving Mrs Rosemary Scott, went to the Supreme Court, which also found in favour of the lenders. ${ }^{11}$

\section{MRS SCOTT'S CASE}

Although there were some differences between the facts in some of the cases, most followed the same pattern, and Mrs Scott's case is representative of them all. Only the facts of this case are therefore described.

Rosemary Scott and her former husband had bought their house, 23 Goathland Avenue, Forest Hill, from North Tyneside Borough Council in 1999 under the government's right to buy scheme, which allowed them, as secure tenants, to buy at a discount below open market value. They took out a mortgage from Cheltenham and Gloucester plc to finance the purchase. A few years later the couple divorced and by 2005 Mrs Scott, who remained in the house, was in financial difficulties. She owed $£ 70,000$ on the mortgage. ${ }^{12}$ She advertised the house for sale at $£ 156,000$, but was unsuccessful at securing a sale close to this price. She was indirectly introduced to a Mr Foster, who was connected to NEPB. He proposed a deal under which NEPB would pay off her Cheltenham and Gloucester mortgage, and give her $£ 24,000$ in cash. She would be allowed to remain in the house indefinitely for $£ 250$ per month rent. NEPB would charge a fee of $£ 40,000$ for this arrangement (this was later

${ }^{8}$ Lord Clarke in Scott refers to ten cases [3] but only nine were involved in the first instance hearing before Judge Behrens.

9 Various Mortgagors v Various Mortgagees [2010] EWHC 2991 (Judge Behrens).

${ }^{10}$ Cook v The Mortgage Business Plc [2012] EWCA Civ 17 (Cook).

${ }^{11}$ Scott v Southern Pacific Mortgages Ltd [2014] UKSC 52 (Scott).

${ }^{12}$ We do not know how much was paid when the property was purchased from the Council, but it was almost certainly significantly less than this: an online search shows that a similar house next door was purchased for $£ 37,500$ in 2002 . The amount of the mortgage may have been increased after the purchase either to pay for improvements or to buy out Mr Scott's share of the property. There may also have been accrued arrears of interest. 
directed to be paid to UK Property Buyers). If Mrs Scott remained a tenant for ten years, she would be paid a further $£ 15,000$ as a loyalty bonus. If anything happened to her, she was told, her son Richard would be able to take over her rights. ${ }^{13}$ The offer may have seemed like an answer to her prayers: she would pay off her mortgage, have lower monthly charges, and have cash in hand.

Mrs Scott agreed to this deal, and so the property was sold in 2005 to a Ms Wilkinson (acting as a nominee or agent for NEPB). The sale price recorded was $£ 135,000$ and completion took place on 12 August. Ms Wilkinson obtained a buy-to-let interest-only mortgage for $£ 115,000$ from Southern Pacific Mortgages Ltd ${ }^{14}$ which did not know that Mrs Scott was living in the house and that she had been made a promise that she could continue living there. It is worth noting in this context that because the rights of a person living at the property are often enforceable against a buyer as overriding interests, it is the expected normal practice for the buyer to inspect the property and to make enquiries of any occupier. If the occupier fails to disclose any rights when asked, those rights will normally cease to be enforceable; it is also possible for the buyer to obtain a written waiver from the occupier. Mortgage companies rarely conduct their own enquiries, and rely upon the enquiries made by the buyer and by any valuer. That was the case here. This practice offers little protection to a mortgage company where the buyer (and perhaps also the valuer) is participating in a fraud, or where (as is sometimes the case) the valuer is asked for a "drive-by" valuation which does not involve a visit to the property.

On 16 August Mrs Scott was given a letter confirming the terms of the sale. She was also granted (by UK Property Buyers acting as agents for Ms Wilkinson) a two-year assured shorthold tenancy which stated that at the end of the fixed term it would become a monthly periodic tenancy terminable on not less than two months' notice in writing. This was in breach of the mortgage which contained terms under which only tenancies of up to a year could be granted. At this stage Mrs Scott did not know that the property had been mortgaged. The sale and mortgage were registered on 16 September.

\footnotetext{
${ }^{13}$ See the appendix to Judge Behrens' decision which sets out the promises which were made to the occupiers in all the test cases. It is not normally possible for a tenant under a private tenancy to pass a tenancy on to another family member.

${ }^{14}$ If this mortgage had borne the relatively low interest rate of $3 \%$ the interest payments would have been $£ 287$ per month. A more likely interest rate of $5 \%$ would have required monthly interest payments of $£ 479$. It will be noted that these payments would have substantially exceeded the agreed monthly rent.
} 
It was only in August 2008 that Mrs Scott discovered that there might be a mortgage on the property when she received a letter from North East Property Lettings "suggesting that there had been teething problems following an office move and that some tenants had been receiving letters from mortgage companies stating that the account was in arrears, which, the letter assured Mrs Scott, was incorrect." 15 In 2009, six months later, Mrs Scott accidentally opened a letter addressed to Ms Wilkinson at the house. She learnt from this that, without her knowledge, a possession order had been made on March 17, 2009. She subsequently received a warrant for possession due to be executed on May 20, 2009. This warrant was suspended while Mrs Scott argued her case.

\section{BUY-TO-LET FRAUD}

Although fraud was not proved in this case, the circumstances pointed very strongly to the arrangement being a scam from the outset, and criminal charges were pending at the date of the trial. ${ }^{16}$ The arrangements involved a complex web of parties, including NEPB (of which Lord Neuberger in the Court of Appeal said, "It is unclear what NEPB is or comprises."), ${ }^{17}$ UK Property Buyers, North East Property Lettings, and a number of other individuals including Michael Foster and Amee Wilkinson. There had been some unusual omissions or entries in the mortgage application forms and contract documentation and no visit to the property had been made by the mortgage company. The solicitors advising Mrs Scott or other victims had not all acted professionally, and may have been dishonest, and some of the solicitors in this or similar cases were subject to disciplinary proceedings. ${ }^{18}$ It is very hard to see how the arrangement could have made any commercial sense to NEPB if it had operated as intended.

\section{MRS SCOTT'S ARGUMENT}

The argument for Mrs Scott was relatively straightforward. She was at all material times living in the house. The proprietary rights of an occupier are normally overriding interests binding a buyer even if those rights have not been protected by an entry on the register at the Land Registry,

\footnotetext{
${ }^{15}$ Scott [22].

${ }^{16}$ At the time of writing this article the trials, which were expected to last several months, were in progress but were subject to reporting restrictions.

${ }^{17}$ Cook [8].

${ }^{18}$ Scott [3] and [24].
} 
provided that the rights have not been surrendered or waived as part of the sale. Mrs Scott therefore argued that her rights to the house were overriding interests: she was living in the house when it was sold, and any person acquiring a right in the house did so subject to whatever rights she had. ${ }^{19}$ She could not claim a right to the freehold (since she had agreed to sell it). However, her main argument went, the promise to allow her to remain living in the house for the rest of her life gave her a proprietary interest in the home, and since this was in existence when the mortgage was executed or registered, her interest bound Southern Pacific, the mortgage company. ${ }^{20}$

\section{MRS SCOTT LOSES HER CASE}

The Supreme Court considered that Mrs Scott's case was not made out. Under the Land Registration Act 2002 section 29 the registration of a mortgage gives it priority over all earlier rights except either those recorded on the register or those which constitute overriding interests. ${ }^{21}$ Only proprietary rights can be overriding interests, and to be protected as an overriding interest the proprietary right must be in existence when the mortgage is created. In the view of the Supreme Court, before the sale took place neither NEPB nor its agents had any power to grant a proprietary right to Mrs Scott. Until the date of the sale, she therefore had no proprietary right based on their promises to her. Applying Abbey National Building Society v Cann ${ }^{22}$ the sale and mortgage should be treated as taking effect at the same instant, and therefore it could not be said that her rights came into existence before the mortgage. It followed that the mortgage took priority over the promises to Mrs Scott and the lease in her favour. The mortgage company was accordingly entitled to the order for possession.

\footnotetext{
${ }^{19}$ See Land Registration Act 2002, s 29 and Schedule 3.

${ }^{20}$ If Mrs Scott could claim only a tenancy (a recognised proprietary interest), her rights could be terminated by notice bringing the tenancy to an end. She therefore needed to claim that her rights included the promise that she would be secure in the home so long as she paid the agreed rent.

21 The ordinary rule is that rights take effect in the order in which they are created. The effect of s 29 is that certain rights (such as a registered transfer of ownership or a registered mortgage) operate like a trump card to give precedence over certain (unprotected) earlier rights.

${ }^{22}$ Abbey National Building Society v Cann [1991] 1 AC 56 (Cann).
} 


\section{ABBEY NATIONAL BS V CANN}

At one level the Scott case is a straightforward application of the principles set out in the Cann case. That, however, was a very different case from Scott. Mrs Cann had helped to pay for a house, 7 Hillview, which was being acquired by her son, George, for them both to live in. She knew that he was taking out a mortgage to finance the purchase, but when he failed to keep up the mortgage payments she claimed that she could not be evicted because she had an overriding interest based on her occupation of the property. It was accepted that her financial contribution was sufficient to give her a proprietary interest. ${ }^{23}$ The House of Lords, however, rejected her argument that she was already living in the house when the registered mortgage was made. Although she was in occupation when the mortgage was registered, the House of Lords considered that she needed to be in actual occupation before the mortgage was created, which was when the purchase was completed. ${ }^{24}$ Mrs Cann was not at that point living in the house, and it was not enough that she had started to move her belongings in a few hours before completion. In any event, her proprietary interest could only arise when her son had sufficient title to the house, and that did not happen until completion. However, since in the view of the House of Lords the mortgage took effect at the very same moment that he acquired title, there was no period before the mortgage was created that he could have given her the rights she claimed. ${ }^{25}$ In any event, Mrs Cann knew that the purchase was to be subject to a mortgage, and impliedly authorised or consented to it.

Mrs Scott, unlike Mrs Cann, had no knowledge of the mortgage to Southern Pacific and could not be said to have authorised it or to have agreed to it. Equally, it was indisputable that she was in actual occupation

${ }^{23}$ On the basis of proprietary estoppel, given an assurance by George that she would always have a roof over her head. The same conclusion would probably now be reached on the basis of constructive trust: see Jones $v$ Kernott [2011] UKSC 53 and Stack $v$ Dowden [2007] UKHL 17.

${ }^{24}$ Lord Collins (Scott [47]) suggests that this part of the decision is confirmed by Land Registration Act 2002, Schedule 3, paragraph 2 which refers to 'the time of the disposition.' With respect the language of the Act does not lead inexorably to this conclusion, since the Act also states that a disposition does not operate at law until it has been registered. A different view would, however, be inconvenient.

${ }^{25}$ The House of Lords rejected the argument that there was a momentary fraction of time between George acquiring ownership and the mortgage taking effect. It had been argued that this 'scintilla temporis' allowed Mrs Cann's rights to arise (or to be 'fed') before the mortgage took effect. 
at the relevant date, whatever it was, since she was in actual occupation throughout.

\section{AN INTEREST CREATED BEFORE COMPLETION?}

It was argued for Mrs Scott that she had an interest in 23 Goathland Avenue even before completion. It was said that the contract for sale in favour of Amee Wilkinson, on behalf of NEPB, gave her a sufficient interest in the house to enable her to grant rights to Mrs Scott. There is long authority that as from the date of exchange of contracts for the sale of land, the seller holds on constructive trust for the buyer. ${ }^{26}$ If this gives the buyer an equitable interest, ${ }^{27}$ then surely this should be sufficient to enable to buyer to make commitments which bind the land, subject to any registration requirements. In response to this, Lord Collins pointed out that the constructive trust was of a distinctive kind, and after a careful review of the authorities (a number of which had been concerned with the purported grant of leases by a buyer prior to completion), came to the conclusion that prior to acquiring the legal estate the buyer could create nothing more than personally enforceable contractual rights. ${ }^{28} \mathrm{Mrs}$ Scott therefore had no proprietary interest capable of binding Southern Pacific. A subsidiary argument based on the notion that Mrs Scott made only a partial grant to Ms Wilkinson since she reserved rights for herself was rejected because the court viewed the transaction as a sale and leaseback rather than a grant of only the reversion on the lease. ${ }^{29}$

\section{THE INDIVISIBILITY OF THE CONTRACT}

In the view of Lord Collins, with whom Lord Sumption agreed, even if equitable rights could arise between contract and conveyance, the logic

${ }^{26}$ Lloyds Bank plc v Carrick [1996] 4 All ER 630; Lysaght v Edwards (1876) 2 Ch D 499. In Ireland the existence of this trust has been confirmed by the Land and Conveyancing Law Reform Act 2009 s 52 resolving a doubt created by the Irish Supreme Court decision in Tempany v Hynes [1976] IR 101. See Pearce and Mee Land Law ( $3^{\text {rd }}$ ed, Round Hall Press, Dublin 2011)133-135.

27 In Gordon Hill Trust Ltd v Segall [1941] 2 All ER 379 the Court of Appeal thought that a contract of sale was sufficient to enable the purchaser to describe himself as the 'owner' in a contract to sell the property on prior to completion.

${ }^{28}$ Lady Hale agreed with this, so the Supreme Court was unanimous on this point.

${ }^{29}$ Scott [77]-[78]. Another argument, that Mrs Scott's rights were akin to an unpaid vendor's lien, was also rejected. Ibid [76]. 
of Cann, supported by other authorities, was that in relation to priorities, the contract could not be treated as distinct for legal purposes from completion:

"The contract of sale does, of course, have separate legal effects, but it would be wholly unrealistic to treat the contract for present purposes as a divisible element in this process." 30

Lady Hale and Lords Wilson and Reed disagreed with this rather startling conclusion. It might hold true in a case ${ }^{31}$ where contract, mortgage and completion were all completed on the same day, it could not be treated as "a general proposition applicable to all ordinary domestic conveyancing transactions." 32

\section{KEY ISSUES}

There were two crucial findings in Scott. The first was that a buyer could not, before completion, create any equitable rights capable of binding the land. This was implicit in Cann. The second, directly adopted from Cann, was that completion was indivisible: the purchase and the mortgage were so interconnected that both took effect at the very same moment; each was subject to the other, and neither had priority. ${ }^{33} \mathrm{We}$ should not doubt for a moment that these are policy decisions rather than decisions driven by ineluctable logic.

Most of the legal debate in Cann centred on four cases in the early 1950s dealing with whether a lease granted by a buyer after contract but before completion was binding on a mortgagee which had helped to finance the purchase. In the following discussion these are called "the four cases." 34

${ }^{30}$ Scott [87].

${ }^{31}$ Such as Nationwide Anglia Building Society v Ahmed and Balakrishnan (1995) 70 P \& CR 381.

${ }^{32}$ Scott [120] - [121] and [123].

${ }^{33}$ See Scott [48].

${ }^{34}$ The cases are Coventry Permanent Economic Building Society v Jones [1951] 1 All ER 901 (Jones); Universal Permanent Building Society v Cooke [1952] Ch 95 (CA) (Cooke); Woolwich Equitable Building Society v Marshall [1952] Ch 1 (Marshall) and Church of England Building Society v Piskor [1954] Ch 553 (CA) (Piskor). 


\section{Creation of rights prior to completion}

In regard to the inability to create proprietary rights prior to completion, it does not follow that because, prior to completion, it is impossible for a buyer to create a legal right out of a legal estate he does not have, that it is impossible for him to create an equitable right. It is clear beyond peradventure that a person with an equitable interest under a trust has the power to deal with it. This is explicitly recognised in the Law of Property Act $1925 .^{35}$ A person with only an equitable interest in land is able to create a valid charge, as has been recognised where one of two coowners purports to create a legal charge by forging the signature of the other co-owner. The charge takes effect as an equitable charge binding the share of the person who executed it. ${ }^{36}$ If a contract for sale confers an equitable interest on the purchaser, and there is substantial authority that it does (even though the constructive trust is an unusual one ${ }^{37}$ ), there is no reason in principle why the equitable owner cannot carve rights out of it. ${ }^{38}$ In Jones, the first of the four cases, ${ }^{39}$ Harman $\mathrm{J}$, a very distinguished Chancery judge, thought that a lease entered into by a buyer prior to completion created an effective equitable lease. ${ }^{40}$ Lord Collins says in Scott that in Jones "the tenants only had personal rights against the purchaser" but he omits to mention that this was because Harman J held that the equitable lease, being based on a contract to grant a legal lease, constituted an estate contract, and as such (the property concerned being unregistered land) it was registrable as a Class C(iv)land charge under the Land Charges Act 1925; the failure to register it meant that it was void as against a purchaser for money or money's worth. ${ }^{41}$

35 Section 53(1) (c). See Pearce and Stevens, Trusts and Equitable Obligations $\left(6^{\text {th }}\right.$ ed, Oxford University Press 2015) 198-209.

${ }^{36}$ Thames Guaranty Ltd v Campbell [1985] QB 210 and Mortgage Corporation v Shaire [2000] EWHC Ch 452. See Stevens and Pearce (n 4) para 17.33.

${ }^{37}$ Lloyds Bank plc v Carrick [1996] 4 All ER 630 at 637G where Morritt LJ described it as a trusteeship 'of a peculiar kind.'

${ }^{38}$ See Gordon Hill Trust Ltd v Segall [1941] 2 All ER 379.

39 Coventry Permanent Economic Building Society v Jones [1951] 1 All ER 901, 903.

${ }^{40}$ This is a straightforward application of the rule in Walsh v Lonsdale (1882) 21 Ch D 9.

${ }^{41}$ Coventry Permanent Economic Building Society v Jones [1951] 1 All ER 901, 903-904. 
Only one other of the four cases picks up the question of whether a buyer can create an equitable lease before completion. This is Cooke. ${ }^{42}$ The trial judge had held that an orally created lease made by a buyer prior to completion was binding on the building society which had helped to finance the purchase, and he considered that the lease did not require registration under the Land Charges Act. The tenant succeeded on appeal on a different point, but Jenkins LJ pointed out that the trial judge was wrong on the issue of registration because the Land Charges Act did not confine the need to register estate contracts to those made in writing. ${ }^{43} \mathrm{By}$ making this point he appears to confirm the view, argued by counsel, that the lease took effect in equity prior to completion. Evershed MR, in rebutting the argument that the lease could not be treated as a tenancy by estoppel capable of being enlarged into a legal lease once the buyer received the legal estate, pointed out that the buyer could not confer the privilege of possession on the purported tenant because, prior to completion, she had herself no right to possession. ${ }^{44}$ This remark should be considered in its context and it need not be interpreted as an obstacle in a case like Scott where Mrs Scott was already lawfully in possession and the grant of an equitable lease would simply confirm that she had a continuing right to possession. Moreover, the difficulty identified by Sir Raymond Evershed would not apply to other types of equitable grant, such as a constructive trust based on a financial contribution or a buyer entering into a sub-contract to sell the land. ${ }^{45}$

\section{The indivisibility of completion}

The four cases all dealt with the question of whether the completion of a purchase and the completion of a mortgage used to finance it were indivisible. The mortgage and the formal deed of transfer are separate documents which are separately executed and separately registered. The

\footnotetext{
${ }^{42}$ Universal Permanent Building Society v Cooke [1952] Ch 95 (CA).

${ }^{43}$ Cooke [1952] Ch 95,104.
}

${ }^{44}$ Cooke [1952] Ch 95,103. The same proposition was made by Judge Behrens: Various Mortgagors v Various Mortgagees [2010] EWHC 2991 [54].

${ }^{45}$ It is not uncommon for a buyer, particularly of commercial property, to enter into a contract prior to completion to sell the property being purchased to a new buyer (see Gordon Hill Trust Ltd v Segall [1941] 2 All ER 379). Such subpurchasers in the past have been able to protect their rights by the registration of a notice on the registered title. If Scott is correct in holding that a buyer can create only personal rights prior to completion, such a sub-contract can create personal rights only and therefore cannot be protected by the registration of a notice. 
main argument for indivisibility is that, despite these elements of separation, the two transactions are so closely interlinked and interdependent that they should be treated as if they were a single operation. ${ }^{46}$ The main argument against indivisibility is that it is only once the buyer has acquired title that it is possible to grant a mortgage. Jones ${ }^{47}$ was the only one of these cases to conclude that the two transactions were indivisible, and that there was therefore no moment at which the buyer of a property subject to a mortgage acquired a legal title free from the mortgage. In Marshall ${ }^{48}$ Danckwerts J held that the mortgagee could not rely on this argument because the mortgage deed explicitly acknowledged that the mortgagor had title to the estate. In Cooke $e^{49}$ the Court of Appeal took the same view because the dates of the relevant deeds disclosed that the purchase had been completed a day before the mortgage was signed. In Piskor ${ }^{50}$ the Court of Appeal went further and held that, as a matter of general principle, there would always be a gap (a "scintilla temporis") between the completion of the purchase and the grant of the mortgage.

In Cann in the House of Lords there was some discussion of the process by which mortgage advances are agreed and implemented inevitably where a purchase is subject to a mortgage the borrower will have agreed the mortgage some time before completion, or even frequently before exchange of contracts. In the end the conclusion was that the purchase and the mortgage should be treated as taking effect simultaneously, because they were so interdependent. The House of Lords in Cann considered that Piskor and Marshall were wrongly decided, ${ }^{51}$ the former because it flew in the face of reality to suggest that a purchase which was dependent upon a mortgage could be treated as divisible from it, the latter because it placed too much emphasis upon the recitals in a deed. $^{52}$

\footnotetext{
${ }^{46}$ Even if electronic conveyancing is introduced, eliminating the gap between the execution of a transaction and its registration, the question whether a mortgage and transfer are indivisible remains since the two transactions would still involve different parties and would still not form part of a single operation (unless the system is programmed in a way which produces this effect).

${ }^{47}$ Coventry Permanent Economic Building Society v Jones [1951] 1 All ER 901.

${ }^{48}$ Woolwich Equitable Building Society v Marshall [1952] Ch 1.

${ }^{49}$ Cooke [1952] Ch 95.

${ }^{50}$ Church of England Building Society v Piskor [1954] Ch 553 (CA).

${ }^{51}$ Cann [1990] UKHL 3, 18 and 27-28.

${ }^{52}$ Lady Hale in Scott [110] notes that the separation of the dates of completion and mortgage in Cooke mean that the case may have been correctly decided if the sale and mortgage were not interdependent.
} 
It is very true that George Cann could not have bought 7 Hillview without the aid of the mortgage loan. To that extent the mortgage and the purchase were inextricably linked. But equally, he could not have bought 7 Hillview without the financial contribution from his mother. ${ }^{53}$ Why could it not be said that her rights arose at the very same moment as the completion of the sale and the mortgage? Lord Collins in Scott identified statements of Lord Oliver and Lord Jauncey in Cann which suggested that Mrs Cann had no rights to 7 Hillview prior to completion because until then George had no power to grant them, but those observations would have applied equally to George's power to create a mortgage in favour of the Abbey National. If the Building Society's rights came into operation at the very instant of completion, why does the same logic not apply to the rights of Mrs Cann? ${ }^{54}$

Similarly in Scott, even if the purchase and the mortgage were inextricably linked (despite Mrs Scott not knowing that the purchase would be financed by a mortgage, the purchase and the promise to Mrs Scott were also inextricably linked. The reality of the situation is that the transfer to Amee Wilkinson on behalf of NEPB would not have taken place were it not for the promises that had been made to Mrs Scott. If the purchase of 23 Goathland Avenue was subject from the instant of completion to a mortgage to Southern Pacific, could it not also be treated as subject from the same instant to the right of Mrs Scott to live there for as long as she wanted at the discounted rent? Instead, and rather illogically, the Supreme Court appears to treat the finding that the mortgage and completion are simultaneous as meaning inevitably that Mrs Scott's rights must have come into existence only after the mortgage.

Finding that the rights of Mrs Cann or Mrs Scott arose at the same instant as the mortgage would give rise to an interesting question of priority. The normal rule is that priority is governed by the order of creation of rights. ${ }^{55}$ The registration of a charge or mortgage gives it

53 A contribution which arose from the sale of the house in which they were previously living.

54 The objection that the purchaser cannot grant rights binding the estate until registration applies equally to the mortgage. Lady Hale recognises that, notwithstanding that legal title has not vested in the purchaser; the purchaser's position is different after completion: Scott [113].

55 This is the normal rule for equitable rights and is confirmed by the Land Registration Act 2002 s 28 which states that 'the priority of an interest affecting a registered estate or charge is not affected by a disposition of the estate or charge.' There are special rules which apply to registered charges, if there is more than one (s 48), but these are not relevant in this context. 
priority over "any interest affecting the estate immediately before the disposition whose priority is not protected" as an overriding interest or by virtue of an entry on the register. ${ }^{56}$ If the rights of Mrs Cann or of Mrs Scott only came into existence at the same instant as the sale and mortgage took effect, then none of these three interests would have come into existence before the other, not even momentarily. The impact of this on priorities will be considered later.

\section{THE DECISION OF THE SUPREME COURT}

\section{Was the Supreme Court wrong?}

The conclusion in Cann and Scott that the coincidence of the transfer of title and the mortgage means that the rights of the occupier in each case can have arisen only after the creation of the mortgage is therefore not a logical conclusion, but a policy decision that the mortgage should have priority. That does not mean that the decision is wrong. There are some good arguments why mortgages should have priority in a situation like this. Lord Collins said that "there is ... an important public interest in the security of registered transactions." 57 Nearly two thirds of all house purchases are financed with the aid of a mortgage. If mortgage lending were made more difficult or risky, it might make mortgages harder to obtain or more expensive. On the other hand, the Supreme Court said in Scott that "the court's duty is to apply the law irrespective of an unexpected impact on conveyancing practice and an adverse effect on the risks of secured lending." 58

\section{Lady Hale's Reservations}

Baroness Hale reluctantly agreed with the decision on the grounds that Ms Wilkinson could not grant anything other than personal rights on Mrs Scott up until the date of completion. She had, however, some concern about the harshness of the result. Having earlier ${ }^{59}$ noted that the court had been asked "to distinguish Cann but not to bury it," she confessed to uneasiness with confirming the decision.

\footnotetext{
${ }^{56}$ Land Registration Act 2002 s 29.

57 Scott [25].

${ }^{58}$ Scott [88].

${ }^{59}$ Scott [114].
} 
"First, Cann was not a case in which the vendor had been deceived in any way or been made promises which the purchaser could not keep. Should there not come a point when a vendor who has been tricked out of her property can assert her rights even against a subsequent purchaser or mortgagee? Second, Cann was not a case in which the lenders could be accused of acting irresponsibly in any way. Should there not come a point when the claims of lenders who have failed to heed the obvious warning signs that would have told them that this borrower was not a good risk are postponed to those of vendors who have been made promises that the borrowers cannot keep? Innocence is a comparative concept. There ought to be some middle way between the "all or nothing" approach of the present law." 60

She welcomed the fact that the Law Commission had announced that it intended to review the Land Registration Act 2002 including the impact of fraud.

\section{Were Lady Hale's Reservations justified?}

Baroness Hale was right to have reservations. Although there was no explicit finding of fraud in the case, it is hard to avoid the conclusion that Mrs Scott was made promises that could not be kept. She may have exercised a lack of caution about the arrangement, but she was short of money and used apparently reputable solicitors, ${ }^{61}$ although they were chosen and paid for by NEPB. She must have signed the contract for sale which Lord Collins said provided that the sale would be with vacant possession $^{62}$ although the alternative provision in the conditions of sale stating that the sale was subject to specified tenancies had neither been deleted nor completed. ${ }^{63}$ She should also have seen the requisitions on title which said that arrangements should be made with her about the time at which vacant possession would be given and for arrangements for handing over the keys. ${ }^{64}$ But if there was a degree of fault on her part, Southern Pacific could not avoid all responsibility. The failure to complete or delete the alternatives in the contract should have been

\footnotetext{
${ }^{60}$ Scott [122].

${ }^{61}$ The author confesses to a personal interest. The firm acting for Mrs Scott also acted as his solicitors for his first house purchase.

${ }^{62}$ Scott [78].

${ }^{63}$ Scott [19].

${ }^{64}$ Scott [18].
} 
noticed by them or their solicitors; even though this was a buy-to-let mortgage, neither they nor their agent visited the property, nor was Mrs Scott asked if she had any continuing rights. In this respect Southern Pacific relied on the honesty and candour of the purchaser. The solicitors acting for Mrs Scott also informed Southern Pacific's solicitors that the lenders needed to be informed that part of the proceeds of the sale were being paid to UK Property Buyers, which indicated that this was not a normal outright sale. ${ }^{65}$

Baroness Hale may have been overstating her concern that an irresponsible lender could never be affected by the right of a vendor who was duped into selling by having been given unenforceable promises. There are equitable doctrines which may enable some lenders to be bound. On the principle that "fraud unravels all", a mortgagee who knowingly participates in a fraud will not be able to rely on the mortgage security. ${ }^{66}$ The equitable wrong of knowing receipt of trust property in breach of trust applies to misappropriated property, and the Supreme Court has suggested that it will operate where a bank receiving the proceeds of a dishonest dealing should have been aware from the circumstances that the transaction served no commercial purpose. ${ }^{67}$ Judge Behrens at first instance $^{68}$ correctly thought that the equitable doctrine of notice had no application in registered land ${ }^{69}$ and so rejected the possibility that the mortgagee's priority could be affected by notice of an adverse right. There was no appeal against that finding, which the Court of Appeal thought meant that Mrs Scott was precluded from making the argument that the mortgagees were estopped from enforcing their security if it was established that they had knowledge or notice of the promises made to

\footnotetext{
${ }^{65}$ Scott [91].

${ }^{66}$ See Quennell v Maltby [1979] 1 WLR 318 (mortgage used as a device to avoid Rent Acts protection); Pearce, [1979] CLJ 257. It should be borne in mind, however, that in Midland Bank Trust Co Ltd v Green [1981] AC 513 the House of Lords held that relying on one's legal rights to defeat the rights of another does not, in itself, constitute fraud. There would therefore need to be something more than knowledge of an adverse right to constitute fraud.

${ }^{67}$ Credit Agricole Corporation and Investment Bank v Papadimitriou [2015] 2 All ER 974 [33].

68 Judge Behrens [2010] EWHC 2991.

69 Judge Behrens [64] applying a statement of Lord Wilberforce in Barclays Bank $v$ Boland [1981] AC 487 at 584. See also the Law Commission's criticism of Peffer v Rigg [1978] 3 AER 745 Law Com No. 158 (1987) para 4.15.
} 
Mrs Scott. ${ }^{70}$ With respect there is a significant difference between this and knowledge or notice of the impropriety of a transaction.

\section{EQUAL PRIORITIES}

\section{Is it possible to have equal priorities?}

The idea that priorities can be equal is a novel concept in land law. Judge Behrens at first instance thought that this was not possible. In his view 'There cannot in law be a 'dead heat' between two mutually inconsistent and competing interests over a legal estate in land. There must be a priority as between them." ${ }^{\prime 11}$ However, a dead heat indeed appears to be the outcome of the conclusion that rights which a purchaser purports to create between contract and completion can only take effect at the moment of completion. The House of Lords in Cann concluded that this meant that the mortgage had priority, but it has already argued that there is no a priori reason why it should have been given this preference. To explore this further, consider this scenario. If $\mathrm{P}$ buys a house with money stolen from B, B can assert a claim to an equitable interest in or charge over the house. This claim cannot take effect prior to completion, because of the rule derived from Scott and Cann that a purchaser cannot create rights binding an estate prior to completion and also because until that stage none of the money has been invested in the purchase. The equitable interest or charge will arise at the moment of completion. But suppose that the purchase is also supported by money raised on mortgage. The mortgagee's claim to the property also arises at the moment of completion. Apart from the effect of registering the charge, it is hard to see how the priorities could be anything other than equal. Registering the charge, however, makes no difference to priorities, because registering a charge only confers priority over unprotected rights affecting the estate "immediately before the disposition.", It would require a stretch of purposive interpretation to interpret that phrase as describing rights which came into existence only at the same time. In consequence, there would be two rights with equal priority. The same consequence would arise if a dishonest purchaser funds a purchase with money stolen from two or more sources. ${ }^{73}$

\footnotetext{
${ }^{70}$ Cook [2012] EWCA Civ 17 [66].

${ }^{71}$ Judge Behrens [2010] EWHC 2991 [52].

${ }^{72}$ Land Registration Act 2002 s 29.

73 The financial advantage to the fraudster in this situation could arise either through collusion with the vendor or because the purchase is from another entity
} 


\section{Priorities involving registrable dispositions}

There are a number of ways in which potentially equal priorities can be addressed. It is often assumed that where a priority issue arises between interests that require registration as registrable dispositions, the normal order of priority is the order in which they are registered. ${ }^{74}$ That order will normally follow the date and time of receipt of the registrable disposition (subject to any priority notice), but where applications are deemed to have been received at the same time ${ }^{75}$ the order of priority is as the parties agree, ${ }^{76}$ with the Land Registrar having tie-breaking power. However, "Where one transaction is dependent upon another the registrar must assume (unless the contrary appears) that the applicants have specified that the applications will have priority so as to give effect to the sequence of the documents effecting the transactions."77 Since the creation of a mortgage is dependent upon the grantor having an estate which can be charged, this would appear potentially to be at odds with the ruling in Cann and Scott, although of course that ruling was based on both purchase and mortgage being mutually interdependent, a situation not envisaged in this clause.

\section{Priorities involving dispositions which are not both registrable}

Where a question of priorities arises between rights which are not both registrable dispositions, two equitable maxims may be relevant. The first is that where equities are equal, the first in time prevails. That will be of no assistance where the priorities issue arises because the rights arise at the same moment. The second is that where equities are equal, the law prevails. That would confirm the outcome in Cann and Scott provided that

under the control of the fraudster: compare Target Holdings v Redferns [1995] UKHL 10.

${ }^{74}$ This is in part because the priority rule in Land Registration Act 2002 s 29 gives registered dispositions priority over earlier unprotected interests. In relation to mortgages the rule used to be that the date of registration (not of creation) governed priority between mortgages (Land Registration Act 1925 s 29). The 2002 Act is less explicit, but the Land Registration Act 2002 s 48 and Land Registration Rules 2003 rule 102 in combination have the same effect.

${ }^{75}$ Under Land Registration Rules 2003 rule 15 this can happen where there is a delay in recording the time of receipt.

${ }^{76}$ Land Registration Rules 2003 rule 55.

${ }^{77}$ Land Registration Rules 2003 rule 55(7). 
the equities are, indeed, equal. However, where the equities are not equal, for instance, borrowing Lady Hale's observation, because the parties are not equally innocent, a different outcome would be justified, and the court can give the more innocent party priority.

In addition, it should not be overlooked that there can be situations where the courts have to resolve equal priorities. Where a trustee has misappropriated and mixed funds from two different sources, for instance where the author of a Ponzi scheme has taken investments from a range of different individuals and put them in a common fund, the preferred judicial solution is that the defrauded individuals should share the fund proportionately to their contribution to it. ${ }^{78}$ It may be objected that the principle of share and share alike can apply only to financial contributions, and so could have no application to a situation like Scott, where Mrs Scott's claim was primarily to a right to live in the house for a discounted rent. ${ }^{79}$ However, rights of residence are capable of actuarial valuation, ${ }^{80}$ and where the interest claimed arises from an estoppel equity, the courts have long asserted a right to assess appropriate compensation rather than conferring a right in specie. ${ }^{81}$ Finally, there appears to be no reason in principle why the courts should not be able to use principles of equitable accounting to resolve competing rights having equal priority. They have long done so in unravelling the affairs of co-owners whose relationship has broken down. ${ }^{82}$

\section{THE IMPACT ON THE PARTIES}

\section{Mrs Scott}

The decision of the Supreme Court in Scott left Mrs Scott at risk of losing her home of many years. However, her financial loss may not have been as great as might at first sight appear. She had put her house on the market for $£ 156,000$ and, if the promises from NEPB on the sale were not enforceable, received just $£ 94,000$ for it. That may make it seem that she could have lost as much as $£ 62,000$ compared with the open market value

\footnotetext{
${ }^{78}$ See Barlow Clowes International Ltd $v$ Vaughan [1992] 4 All ER 22. See the discussion in Pearce and Stevens, Trusts and Equitable Obligations $\left(6^{\text {th }} \mathrm{ed}\right.$, OUP 2015) 978-983.

${ }^{79}$ She had also been promised a further payment of $£ 15,000$ after ten years.

${ }^{80}$ See Bracken v Byrne [2006] ILRM 91.

${ }^{81}$ Dodsworth v Dodsworth (1973) 228 EG 1115. See the discussion in Stevens and Pearce (n 4) 734-746.

${ }^{82}$ Stevens and Pearce (n 4) 411-420.
} 
of her house. However, most or all of the houses in Goathland Avenue were former council houses built at the same time and to a similar specification, and none has ever sold for anything close to the price which Mrs Scott was asking. According to Land Registry data, the immediately neighbouring property on one side (number 21) sold for $£ 130,000$ in 2009 and the immediate next door property on the other side (number 25) sold for $£ 112,000$ in 2014. Even the price of $£ 135,000$ for which the Land Registry records Mrs Scott's sale as having taken place in 2005 may have been high ${ }^{83}$ unless 23 Goathland Avenue was a particularly attractive property compared with its neighbours. ${ }^{84} \mathrm{~A}$ better estimate of the extent to which Mrs Scott personally received less than full open market value is therefore that it was probably less than the $£ 40,000$ which NEPB had identified as its "cut". If the property was being sold on the open market subject to Mrs Scott's right to remain at a rent of $£ 250$ per month, then this would have reduced the market value of the house subject to her tenancy by around $25 \%$ or more, and might not have been enough even to redeem her mortgage. A more cautious person than Mrs Scott might have realised that the deal was too good to be true.

Mrs Scott knew when she struck her deal with Mr Foster that she would cease to own her own home. However, she did expect to be able to stay on as a tenant for $£ 250$ per month, and that represented a substantial benefit compared with normal market rents, which at usual rates of return on rental properties ${ }^{85}$ is likely to have been in the order of $£ 500$ to $£ 650$ per calendar month. Mrs Scott gained some benefit from that discounted rent since at least three and a half years elapsed before she was served with the order for possession. That represents a saving of around $£ 11,000$ in rent.

${ }^{83}$ Since NEPB was 'retaining' $£ 40,000$ of this price, the real sale price was $£ 95,000$. The price may have been inflated in order to enable a higher mortgage loan to be obtained. See the Law Society description of Equity Release Fraud in its Practice Note on Mortgage Fraud para 2.4.1

http://www.lawsociety.org.uk/support-services/advice/practice-notes/mortgagefraud/ accessed June 2015.

${ }^{84}$ Rightmove data suggests that average house prices in the NE12 area rose by about $10 \%$ from 2005 to 2008 , with relatively little movement over the period 2006-2014, apart from a modest peak in 2008. See http://www.rightmove.co.uk/house-prices-in-myarea/marketTrendsTotalPropertiesSoldAndAveragePrice.html?searchLocation=ne 12+8ha\&sellersPriceGuide=Start+Search accessed June 2015.

${ }^{85}$ Typically this is a gross rent of $5 \%$ of the property value, although there are significant variations from this average. 


\section{North East Property Buyers}

NEPB appears to have set up this kind of arrangement for at least 100 properties, and possibly very considerably more. It might seem that NEPB stood to benefit by $£ 40,000$ on 23 Goathland Avenue - the fee that it was claiming for the deal - but its actual "turn" is likely to have been far less than this because the sale price of $£ 135,000$ was never paid. Ms Wilkinson, on NEPB's behalf, took out a mortgage of $£ 115,000$ ( $£ 113,000$ after fees), which is the only money that NEPB ever received on this property. Out of this it discharged Mrs Scott's mortgage and paid her $£ 24,000$. This left a balance of $£ 19,000$ less expenses, plus any rent which Mrs Scott paid. Against this, it incurred mortgage interest charges (which cannot have been paid in full) which would have amounted over three and a half years to about $£ 15,000$ to $£ 20,000$, exceeding the rent which Mrs Scott paid, and wiping out a significant proportion of the capital it received. Furthermore, if NEPB met the terms of its bargain, it would not be able to sell the property with vacant possession while Mrs Scott or her son wished to live in the house, and it also had a liability to pay her a further $£ 15,000$ after ten years. It could only make a profit from this arrangement if it was fraudulent and it did not meet its obligations.

\section{Southern Pacific Mortgages Ltd}

Southern Pacific lent Ms Wilkinson $£ 115,000$. If the property was genuinely worth $£ 135,000$ at the time of the mortgage, it had good security for the loan, but there is a strong possibility that the price of the property was inflated in order to enable NEPB to obtain a higher loan than would otherwise have been the case. By the time of trial, it is likely that the mortgage debt would have increased greatly in consequence of accumulated arrears of interest and legal fees. Southern Pacific would therefore be unlikely to repay the debt in full even from a sale of the property with vacant possession. The Supreme Court did ask the mortgagee to show mercy. Lord Collins said 'I express the hope that the lenders will, before finally enforcing their security, consider whether they are able to mitigate any hardship which may be caused to the vendors. ${ }^{86}$ As at June 2015 (eight months after the judgment) there was no indication from publicly available records that 23 Goathland Avenue had been sold or was actively being marketed for sale. There is therefore a strong possibility that Southern Pacific have agreed to defer enforcing their

${ }^{86}$ Scott [94]. 
security on terms that Mrs Scott makes periodical payments towards mortgage interest.

\section{What might have happened if there was full disclosure?}

Southern Pacific would not have agreed to a mortgage based on full open market value if it knew that it was purchasing a property which was subject to a tenancy at a discounted rent, since this would significantly have depressed the value of the property. They were prepared to lend on a buy to let basis, but the mortgage terms envisaged that Ms Wilkinson could grant only assured shorthold tenancies with a maximum duration of six months before becoming period tenancies determinable on two months' notice. A tenancy of this duration would not have given Mrs Scott the rights she was expecting. The lease which was actually granted to Mrs Scott was for a fixed two year term, thereafter determinable by two months notice. Even if this had been binding on Southern Pacific, it would have given Mrs Scott negligible protection because by the time possession proceedings began the two year fixed term had long expired.

Mrs Scott had, however, been led to believe that she could stay in 23 Goathland Avenue as long as she wanted. It is not actually possible in law to grant a tenancy which cannot be terminated by the landlord so long as the tenant wishes to remain in possession, since the Supreme Court has affirmed the rule that leases must have a fixed duration. ${ }^{87}$ There are some drafting techniques which can avoid this rule, such as granting a lease for 99 years with a provision allowing notice to be given by the landlord only after Mrs Scott's death, but of course nothing like this was drafted by NEPB ${ }^{88}$ It is also possible for an agreement intended to create a tenancy for an uncertain term which cannot be terminated during the lifetime of the tenant to be treated as a lease for life which will be converted automatically by statute into a lease for 90 years determinable on the death of the tenant, ${ }^{89}$ but again this was inconsistent with the documentation drafted by NEPB.

The promise to allow Mrs Scott to remain in 23 Goathland Avenue for as long as she wished could be treated as a contractual licence, ${ }^{90}$ but this would be enforceable only between Mrs Scott and NEPB, and would not create any interest binding on Southern Pacific. It therefore seems that,

\footnotetext{
${ }^{87}$ Berrisford v Mexfield Housing Co-operative Ltd [2011] UKSC 52.

${ }^{88}$ Provision could also be made to allow Mrs Scott's son to succeed to the tenancy.

${ }^{89}$ Berrisford v Mexfield Housing Co-operative Ltd [2011] UKSC 52.

${ }^{90}$ Southward Housing Co-Operative Ltd v Walker [2015] EWHC 1615 [95].
} 
even if Southern Pacific had been fully aware of the circumstances, the relatively vague and informal promises to Mrs Scott would have meant that only an interest arising by proprietary estoppel could have been asserted with any prospect of success. It is unlikely that any lender would want to advance funds knowing that it was bound by promises like those made to Mrs Scott. Since NEPB required mortgage funding for its model, it follows that the deal with NEPB could not have been executed. Absent a white knight, the only option left to Mrs Scott would have been to reduce substantially the asking price she was seeking for her house, to sell, and to move into rented accommodation for which she would have to pay the full market rent. She might have had a little more capital (depending upon the sale price she was able to obtain), but her overall position would not have been vastly different from that she found herself in as a result of the failure by NEPB to honour its promises.

\section{CONCLUSION}

\section{Implications for the future}

Lord Collins claimed that the kind of arrangement examined in Scott was now relatively rare. He explained that sale and leaseback arrangements had become very popular in the early part of the century, but they came within the regulatory authority of the Financial Services Authority in 2009, and by February 2012 the FSA reported that in practice the entire market had shut down. ${ }^{91}$ With respect, while it may indeed be true that sale and leaseback arrangements can no longer legitimately be marketed, it does not follow that they are not offered illegitimately by unscrupulous operators. Ponzi schemes are illegal, but almost every year a new example comes to light. Mrs Scott's real problem was not that she entered into a sale and leaseback scheme, but that she was induced to sell her home by promises which could never have been honoured, and which were probably never intended to be honoured. She was almost certainly the victim of fraud, and fraud is, regrettably, only too common. Lord Collins is therefore wrong to dismiss Rosemary Scott's case as an isolated example which is unlikely again to occur. The implications of the case have far wider implications than just for the several score cases which were awaiting the outcome of the Supreme Court decision.

${ }^{91} \operatorname{Scott}[1][2]$. 


\section{Magna Carta and the Rule of Law}

The primary motivation of the barons when they compelled King John to accede to the Great Charter was undoubtedly the protection of their own privileges and freedoms. However, Magna Carta has proved to be the bedrock on which have been laid those great cornerstones of our constitution, the principles of democracy and the rule of law. Freedom from the arbitrary or capricious depredations of the Crown - an aspect of the rule of law directly traceable to Magna Carta - has given real substance to the maxim that an Englishman's home is his castle. What the North East Property Buyers litigation demonstrates is that this protection is not enough to keep a person secure in their own home. The litigation shows that the defences of the Englishman's castle are not absolute, and that the castle walls may come tumbling down from attacks from other quarters. The source of that attack may not be obvious. Donald Rumsfeld famously said:

"There are known knowns; there are things we know we know. We also know there are known unknowns; that is to say we know there are some things we do not know. But there are also unknown unknowns, the ones we don't know we don't know." 92

Mrs Scott would have known that if she did not pay her mortgage before the deal with NEPB, or her rent thereafter, that her home might be repossessed. She probably knew that she did not know how she would be able to finance her own mortgage if she had been unable to find a buyer and the offer from NEPB had not been made. But what she almost certainly did not know that she did not know was that the promises which NEPB had made were in practice worthless, that it had used a mortgage to finance the transaction, and that if it did not keep up the mortgage payments her home might be repossessed.

Tenants know that if they do not pay the rent they are likely to lose their home; very few of them will be aware that if their landlord has a mortgage which remains unpaid, they may also face repossession.

\footnotetext{
${ }^{92}$ Donald Rumsfeld, US Secretary of State, on 12 February, 2002, answering a question at a press conference about the evidence showing Iraq's possession of weapons of mass destruction.
} 
The personal impact

Fraud - which was almost certainly involved in this case - has a shattering upon its victims. Few are likely to cry for the mortgage company, which although impacted, has relatively broad shoulders and can amortise the effect of the fraud across other parts of its portfolio. The effect upon the householders who have been deluded by unenforceable promises is much more stark. Paula Harris, who was the lead solicitor acting for the tenants in the North East Property Buyers litigation has said of the Supreme Court decision:

"The Judgment is a devastating disappointment for the tenants.... The Supreme Court has made it very clear that the tenants are innocent victims in this matter, but the current law does not give those tenants a right which takes priority over a mortgage company. However, the Law Commission is currently consulting on reforms which we hope will protect tenants in similar situations in future. Sadly, this will not be in time to help those unfortunate, innocent tenants of NEPB." $" 93$

${ }^{93}$ See http://www.davidgray.co.uk/2014/10/north-east-property-buyers-litigationthe-supreme-court-gives-judgment/ accessed June 2015. 